\title{
Ocena rządowego projektu ustawy o jednorazowym świadczeniu pieniężnym dla emerytów i rencistów w 2019 r. $^{1}$
}

Assessment of the governmental Bill on One-off Cash benefit for Pensioners and Disability Pensioners in 2019: The governmental bill implements of the announced, socalled "thirteenth" pension benefit for each retired citizen. The author estimates that the act aims at reducing income disparities in society, and the government's bill effectively implements this social objective. This law has far-reaching financial consequences, which may cause the need for transfers in the budget and financial plans of state special purpose funds. In the author's opinion, this may lead to an amendment of the budget law increasing the level of the budget deficit, especially if other electoral promises will be implemented or economic downturn will occur.

Keywords: retirement and disability pensions, bill, social security

Słowa kluczowe: emerytury i renty, projekt ustawy, zabezpieczenia społeczne

\section{Przedmiot projektu}

Projektowana ustawa określa warunki nabywania prawa do jednorazowego świadczenia pieniężnego $\mathrm{w}$ kwocie $1100 \mathrm{zł}$ brutto (netto $888,25 \mathrm{zł})^{2}$ przysługującego w 2019 r. osobom uprawnionym, tj. emerytom i rencistom ${ }^{3}$ oraz zasady jego wypłaty. Tym samym proponowane rozwiązanie dotyczyć ma emerytur i rent w systemie powszechnym, emerytur i rent rolników, służb mundurowych, eme-

1 Ocena skutków regulacji rządowego projektu ustawy o jednorazowym świadczeniu pieniężnym dla emerytów i rencistów w 2019 r. (druk nr 3311) sporządzona 29 marca 2019 r. na zlecenie zastępcy Szefa Kancelarii Sejmu; BAS-WASiE 645/19.

2 Zob. art. 5 i 11 projektowanej ustawy. Jednorazowe świadczenie pieniężne zostanie wypłacone w kwocie pomniejszonej o podatek dochodowy od osób fizycznych oraz składkę na ubezpieczenie zdrowotne.

3 Osoby uprawnione zostały określone w art. 2 ust. 2 projektowanej ustawy. 
rytur pomostowych, świadczeń i zasiłków przedemerytalnych, rent socjalnych, nauczycielskich świadczeń kompensacyjnych, rodzicielskich świadczeń uzupełniających oraz rent inwalidów wojennych i wojskowych.

Rząd zaznacza jednak, że jednorazowe świadczenie pieniężne nie będzie przysługiwać osobom, którym prawo do świadczeń zostało zawieszone na dzień 30 kwietnia 2019 r., przy czym prawo do jednorazowego świadczenia pieniężnego będzie podlegać ponownemu ustaleniu (weryfikacji), jeżeli okaże się, że prawo do świadczenia np. emerytury lub renty nie istniało (np. ze względu na przedłożenie nieprawdziwych dokumentów), podlegało zawieszeniu (np. ze względu na przekroczenie maksymalnego limitu dochodu, rzutującego na wypłatę np. renty) lub przysługiwała wypłata świadczenia (np. sprawa zakończona wyrokiem sądu przyznającego prawo do emerytury lub renty albo świadczenie to zostało na wniosek emeryta/rencisty zawieszone, ale nie było do tego uzasadnienia), (art. 2 ust. 3 i 4 projektu). Wówczas, po uzyskaniu informacji o zaistniałych faktach, jednorazowe świadczenie pieniężne zostanie przyznane lub zostanie ono uznane za nienależnie pobrane.

Ponadto projekt ustawy nie obejmie sędziów oraz prokuratorów w stanie spoczynku, ponieważ nie mają oni statusu emeryta lub rencisty ${ }^{4}$.

Projekt zawiera też zasadę stosowaną w systemie emerytalnym polegającą na tym, że w razie zbiegu prawa do więcej niż jednego świadczenia, osobie uprawnionej będzie przysługiwać jedno jednorazowe świadczenie pieniężne (art. 3 projektu). Tak samo jedno jednorazowe świadczenie pieniężne będzie przysługiwać również do renty rodzinnej, do której jest uprawniona więcej niż jedna osoba (świadczenie to będzie podlegać proporcjonalnemu podziałowi na osoby uprawnione do renty rodzinnej). W przypadku zaś, gdy do renty rodzinnej jest uprawniona więcej niż jedna osoba i przynajmniej jedna $z$ nich jest uprawniona do renty socjalnej, jednorazowe świadczenie pieniężne z tytułu renty rodzinnej będzie podlegać podziałowi stosownie do liczby osób uprawnionych do renty rodzinnej, z wyłączeniem osoby lub osób uprawnionych do renty socjalnej. Osobie lub osobom wyłączonym z liczby osób uprawnionych do renty rodzinnej będzie przysługiwać jednorazowe świadczenie pieniężne z tytułu przysługującego prawa do renty socjalnej (art. 4 projektu).

Jednorazowe świadczenia pieniężne byłyby wypłacone $\mathrm{z}$ urzędu wraz ze świadczeniem w terminie wypłaty świadczeń przypadającym w maju, z wyjątkami przewidzianymi do wypłaty w czerwcu i lipcu (art. 6 projektu). Natomiast decyzje w sprawie jednorazowego świadczenia pieniężnego będą wydawane i świadczenia te będą wypłacane przez właściwe organy emerytalno-rentowe (art. 7 ust. 1 projektu). W razie zaś zbiegu prawa do świadczeń, które są wy-

4 Jak wskazuje się w uzasadnieniu projektu, przejście w stan spoczynku nie zmienia charakteru prawnego uposażenia pobieranego w okresie czynnej służby. Jest to świadczenie związane ze statusem sędziego lub prokuratora mające charakter dożywotni. 
płacane przez dwa organy, decyzje będą wydawane i jednorazowe świadczenie pieniężne wypłacane przez ZUS (art. 7 ust. 2 projektu).

Kolejnym rozwiązaniem przyjętym w projekcie (art. 8 i 9 projektu) jest to, że kwota jednorazowego świadczenia pieniężnego nie będzie się wliczała do dochodu, o którym mowa w ustawie o podatku dochodowym od osób fizycznych (art. 26 ust. 7e), ustawie o dodatkach mieszkaniowych (art. 3 ust. 3), ustawie o świadczeniach rodzinnych (art. 3 pkt 1), ustawie o pomocy społecznej (art. 8 ust. 3), ustawie o pomocy osobom uprawnionym do alimentów (art. 2 pkt 4) oraz ustawie o pomocy państwa w wychowywaniu dzieci (art. 5 ust. 3 i 4). Kwota jednorazowego świadczenia pieniężnego nie będzie się też wliczała do przychodu, o którym mowa w ustawie o rencie socjalnej (art. 10 ust. 5). To oznacza, że kwota jednorazowego świadczenia pieniężnego nie będzie miała wpływu na uprawnienia osób ubiegających się o świadczenia, dodatki, zasiłki, pomoc lub wsparcie (np. ulga rehabilitacyjna) wymienione w powołanych ustawach. Z kwoty jednorazowego świadczenia pieniężnego nie będą mogły być też dokonywane potrącenia i egzekucje (art. 10 projektu).

Projektowana ustawa zmienia ustawę o promocji zatrudnienia i instytucjach rynku pracy po to, aby jednorazowe świadczenie pieniężne dla osób, które w dniu 30 kwietnia 2019 r. będą miały prawo do świadczenia przedemerytalnego lub zasiłku przedemerytalnego, mogło być sfinansowane ze środków Funduszu Pracy. W tym też celu minister właściwy do spraw pracy, na wniosek Prezesa ZUS, przekaże w 2019 r. środki Funduszu Pracy na wyodrębniony rachunek bankowy Zakładu Ubezpieczeń Społecznych (art. 13 projektu).

W celu sprawnej realizacji ustawy Minister Finansów będzie mógł dokonywać przeniesień wydatków budżetowych na wniosek właściwego dysponenta części budżetowej, tj. przeniesień między działami, rozdziałami i paragrafami klasyfikacji wydatków budżetu państwa oraz między częściami budżetowymi 72 - Kasa Rolniczego Ubezpieczenia Społecznego oraz 73 - Zakład Ubezpieczeń Społecznych (art. 15 projektu). Dodatkowo projekt ustawy zawiera przepis (art. 14), zgodnie z którym do państwowych funduszy celowych: Funduszu Ubezpieczeń Społecznych, Funduszu Emerytur Pomostowych i Funduszu Emerytalno-Rentowego Kasy Rolniczego Ubezpieczenia Społecznego stosuje się zasadę, że zmiany planu finansowego państwowego funduszu celowego mogą powodować zwiększenie dotacji z budżetu państwa.

Projekt zawiera też postanowienie dotyczące tego, jakie przepisy stosuje się $\mathrm{w}$ sprawach nieuregulowanych w przedmiotowym projekcie ustawy (art. 12 projektu).

Ustawa ma wejść w życie z dniem następującym po dniu ogłoszenia (art. 16 projektu). Wynika to z konieczności przygotowania do technicznej wypłaty świadczenia już w połowie kwietnia 2019 r. Z uwagi na to, że dzień 1 maja 2019 r. jest dniem wolnym od pracy, wypłata jednorazowego świadczenia pieniężnego może trafić do świadczeniobiorców już pod koniec kwietnia 2019 r. 


\section{Podmioty, na które oddziałuje akt}

\section{Ustawa oddziałuje na:}

- osoby uprawnione do otrzymania jednorazowego świadczenia pieniężnego (tj. świadczeniobiorców pobierających emerytury i renty, świadczenia i zasiłki przedemerytalne, renty socjalne oraz rodzicielskie świadczenia uzupełniające przed dniem 1 maja 2019 r.); liczba tych osób jest szacowana na ponad 9,8 mln

- podmioty wypłacające świadczenia (Zakład Ubezpieczeń Społecznych, Kasa Rolniczego Ubezpieczenia Społecznego, organy emerytalne służb mundurowych ${ }^{6}$ ),

- Ministra Finansów, upoważnionego do dokonywania przeniesień wydatków na wniosek określonych dysponentów.

\section{Celowość wprowadzenia aktu}

Projektodawca uzasadnia celowość wprowadzenia ustawy potrzebą wprowadzenia dodatkowej pomocy dla emerytów i rencistów i zmniejszenia różnic dochodowych w społeczeństwie.

\section{Planowane środki (narzędzia i działania) realizacji celów}

Planowane środki (uchwalenie proponowanej ustawy) ułatwią realizację celu przedstawionego przez wnioskodawcę projektu. Emeryci i renciści uzyskają dodatkową pomoc i zmniejszą się różnice dochodowe (kwota 888,25 zł będzie relatywnie więcej znaczyła dla osób pobierających niskie świadczenie (np. z KRUS, gdzie przeciętna miesięczna emerytura i renta brutto w 2017 r. wynosiła $1200 \mathrm{zl)} \mathrm{niż} \mathrm{dla}$ osób, których świadczenie jest wysokie, np. służb mundurowych (ponad 3000 zł) ${ }^{7}$. Ponadto ograniczona może być spadająca relacja emerytury do wynagrodzenia ${ }^{8}$.

5 W tym ok. 6,96 mln emerytów i 2,62 mln rencistów, w tym 282 tys. rencistów socjalnych. Zob. uzasadnienie projektu, s. 5. W „Ocenie skutków regulacji” rządowego projektu (s. 2) podaje się następujące wielkości: 8222 tys. - emerytury i renty z pozarolniczego systemu ubezpieczeń społecznych, 101 tys. - zasiłki i świadczenia przedemerytalne, 282 tys. - renty socjalne, 1141 tys. - emerytury i renty z KRUS, 65 tys. (prognozowana liczba świadczeń) - rodzicielskie świadczenia uzupełniające. Daje to razem 9811 tys. świadczeniobiorców.

$6 \quad$ Emerytury służb mundurowych są wypłacane z budżetu państwa (w ramach budżetu MSWiA, MON i MS), bowiem funkcjonariusze nie opłacają składek do ZUS.

7 Zob. publikacja GUS pt. Emerytury i renty w 2017 r., Warszawa 2018, s. 61.

8 W 2014 r. relacja przeciętnej miesięcznej emerytury brutto z pozarolniczego systemu ubezpieczeń do przeciętnego wynagrodzenia w gospodarce narodowej wynosiła 64\%, w 2015 r. $-63,7 \%$, w 2016 r. $-62,3 \%$ i w 2017 r. - 60,4\%, ibidem, s. 75. 


\section{Ocena kosztów i korzyści}

\section{Skutki finansowe}

Koszt wypłaty jednorazowych świadczeń pieniężnych wyniesie ok. 10,8 mld zł9 . Przy czym zostanie on sfinansowany z wpływów do Funduszu Ubezpieczeń Społecznych, Funduszu Emerytur Pomostowych i Funduszu Pracy oraz ze środków pozostających w dyspozycji pozostałych dysponentów poszczególnych części budżetowych, tj. części 29 - Obrona narodowa, części 37 - Sprawiedliwość oraz części 42 - Sprawy wewnętrzne na 2019 r.

Przewiduje się, że wejście w życie ustawy spowoduje, iż wydatki budżetu państwa zwiększą się o $890 \mathrm{mln}$ zł, wydatki pozostałych podmiotów o $9903 \mathrm{mln}$ zł (w tym ZUS (FUS) - 8508 mln zł, KRUS - 1255 mln zł, Funduszu Pracy $111 \mathrm{mln}$ zł i Funduszu Emerytur Pomostowych - 29 mln zł). Wzrostowi wydatków towarzyszyć będą większe dochody budżetu państwa (o $540 \mathrm{mln}$ zł), budżetów jednostek samorządu terytorialnego (o $540 \mathrm{mln} \mathrm{z}^{10}$ ) i większe wpływy do NFZ (o $971 \mathrm{mln}$ zł) z uwagi na obciążenie jednorazowego świadczenia pieniężnego podatkiem dochodowym od osób fizycznych i składką na ubezpieczenie społeczne. W efekcie saldo dla budżetu państwa będzie ujemne (kwota $350 \mathrm{mln}$ $\mathrm{zł})^{11}$.

Sfinansowanie wypłaty jednorazowych świadczeń pieniężnych z budżetu państwa w szacowanej kwocie $350 \mathrm{mln}$ zł nie powinno być problemem dla budżetu państwa, niemniej zauważyć należy, że:

- Kasa Rolniczego Ubezpieczenia Rolniczego jest w większości finansowana dotacją z budżetu państwa (dotacja stanowi ok. 92\% przychodów). Jednocześnie w planie finansowym Funduszu Emerytalno-Rentowego przyjętym na 2019 r. zakłada się, iż przychody będą minimalnie niższe od kosztów Funduszu w efekcie stan końcowy wyniesie niespełna 38,4 mln zł. To oznacza, że konieczne może stać się zwiększenie dotacji z budżetu państwa do tego Funduszu w kwocie potrzebnej na wypłatę świadczenia jednorazowego lub też zaakceptowanie ujemnego stanu Funduszu,

- Fundusz Ubezpieczeń Społecznych - aczkolwiek finansowany jest głównie ze składek (składki stanową ok. 76,4\% przychodów Funduszu), to jednak w planie na 2019 r. koszty Funduszu będą wyższe niż przychody, w efekcie stan końcowy ma zamknąć się kwotą 1677,5 mln zł. To oznacza, że dla zwiększenia wydatków na kwotę 8508 mln zł brakować będzie środków. Konieczne

99811 tys. świadczeniobiorców x 1100 zł = 10792100 zł.

10 Przypomnieć należy, że łączny udział jednostek samorządu terytorialnego we wpływach z PIT miał wynieść w 2019 r. 49,93\%, zob. uzasadnienie ustawy budżetowej na rok 2019, s. 27; zob. też art. 4 ust. 2, art. 5 ust. 2 i art. 6 ust. 2 ustawy o dochodach jednostek samorządu terytorialnego.

11 Zob. „Ocenę skutków regulacji” do projektu ustawy. 
może być zwiększenie dotacji z budżetu państwa lub udzielenie pożyczki na pokrycie wydatków Funduszu. Nie można też wykluczyć, że FUS - tak jak bywało to wcześniej - wykaże ujemny stan Funduszu,

- Fundusz Emerytur Pomostowych na 2019 r. zaplanował przychody prawie równe wydatkom, i niewielkie środki na koniec roku (12,6 mln zł). To oznacza, że nie będzie w stanie pokryć wydatków na kwotę ponad dwukrotnie wyższą (29 mln zł),

- Fundusz Pracy ma wyższe przychody niż koszty realizacji zadań oraz dość wysoki stan końcowy (20 653,5 mln zł), stąd też możliwe wydaje się sfinansowanie wydatków związanych z jednorazowymi świadczeniami pieniężnymi.

Reasumując, należy wskazać, że obciążenie budżetu państwa może być wyższe niż wykazywane w „Ocenie skutków regulacji” rządowego projektu. Niemniej warto pamiętać, że w bieżącym roku uprawnienia do dokonywania przeniesień wydatków są szersze niż w latach wcześniejszych ${ }^{12}$, uprawnienia takie przewiduje też projekt niniejszej ustawy (art. 14), który zawiera unormowanie, że do państwowych funduszy celowych: FUS, FEP i Funduszu Emerytalno-Rentowego KRUS stosuje się zasadę, że zmiany planu finansowego państwowego funduszu celowego mogą powodować zwiększenie dotacji z budżetu państwa. Należy też pamiętać, że w pierwszej połowie roku Minister Finansów ma większe pole manewru i sfinansowanie nowego wydatku może być łatwiejsze, bowiem wiele wydatków, zwłaszcza inwestycyjnych, realizowanych jest później, m.in. z uwagi na procedury zamówień publicznych, poza tym pojawiają się też tzw. naturalne oszczędności budżetowe. Oczywiście nie można wykluczać nowelizacji ustawy budżetowej, np. na skutek niespodziewanego pogorszenia koniunktury gospodarczej skutkującej załamaniem się wpływów budżetowych i zwiększeniem poziomu deficytu i potrzeb pożyczkowych państwa czy na skutek realizacji dalszych obietnic wyborczych ${ }^{13}$.

12 Zob. ustawa z 9 listopada 2018 r. o szczególnych rozwiązaniach służących realizacji ustawy budżetowej na rok 2019 (Dz.U. poz. 2435) oraz art. 30 ustawy z 20 lipca 2018 r. o zmianie ustawy o Inspekcji Ochrony Środowiska oraz niektórych innych ustaw (Dz.U. poz. 1479).

13 Na konwencji PiS złożonych zostało pięć obietnic: świadczenie wychowawcze z programu „Rodzina 500 Plus” na każde dziecko, „trzynasta emerytura” w wysokości najniżej emerytury z ZUS, zerowy PIT dla pracujących do 26. roku życia, obniżenie kosztów pracy oraz przywrócenie lokalnych połączeń autobusowych. Krytyczne wypowiedzi na ten temat zob. m.in. https://finanse.gazetaprawna.pl/artykuly/1404819,ekonomisci-przestrzegaja-przed-skutkami-5-pis-piatki-pis-list-kotecki.html, http://www.msn. $\mathrm{com} / \mathrm{pl}$-pl/wiadomosci/opinie/to-w-ko\%c5\%84cu-pieni\%c4\%85dze-na-wyborcze-obietnice-s\%c4\%85-czy-ich-nie-ma/ar-BBVjbBQ?li=BBr5CAq\&ocid=iehp, https:// www.rp.pl/Budzet-i-Podatki/303189897-Ile-budzet-zarobi--na-nowej-piatce-PiS. 
Gdyby jednak przyjąć założenie, że należałoby zwiększyć poziom dotacji o ok. 9 mld zł, to poziom deficytu budżetu państwa zwiększyłby się z kwoty $28,5 \mathrm{mld}$ zł do 37,5 mld zł i stanowiłby 1,7\% PKB planowanego na rok bieżący.

Trudno jest obecnie określić, jak wpłynie to na średniookresowy cel budżetowy (MTO), niemniej przypomnieć należy, że Polsce nie udaje się osiągać tego celu wyznaczonego na $1 \%$ PKB w ujęciu strukturalnym ${ }^{14}$ i najprawdopodobniej nie uda się to do roku 2022. Warto jednak pamiętać, iż znaczne odstąpienie od ścieżki dostosowawczej prowadzącej do osiągnięcia MTO, w świetle uzgodnionych zmian, jest przesłanką do skierowania przez Komisję Europejską ostrzeżenia pod adresem danego $\mathrm{kraju}^{15}$.

\section{Skutki społeczne}

Wypłata jednorazowego świadczenia pieniężnego rodzić będzie pozytywne skutki dla znacznej grupy społecznej, jaką są emeryci i renciści, w tym też osób niepełnosprawnych i starszych. Dane GUS wskazują, że gospodarstwa domowe emerytów i rencistów mają trudności w zaspokajaniu swoich potrzeb ${ }^{16}$. W ujęciu relatywnym $w$ największym stopniu beneficjentami ustawy będą najubożsi emeryci i renciści. Dochód tej grupy osób z pierwszej grupy decylowej wzrośnie o ok. $2,4 \%{ }^{17}$.

Aczkolwiek projekt ustawy wprowadza świadczenie jednorazowe tylko na 2019 r., to jednak w przyszłości nie można wykluczać podobnych działań (o ile pozwolą na to możliwości budżetowe). Jest to wysoce prawdopodobne, zważywszy na to, że stopa zastąpienia obrazująca stosunek wysokości pierwszej emerytury do wysokości ostatniej pensji jest w Polsce bardzo niska ${ }^{18} \mathrm{i}$ będzie coraz

html, https://www.rp.pl/Budzet-i-Podatki/303209904-Ekonomisci-ostrzegaja-politykow-przed-beztroska.html [dostęp 27 marca 2019 r.].

14 Zob. https://eur-lex.europa.eu/legal-content/PL/TXT/PDF/?uri=CELEX:32018H0 910(20)\&from=EN, https://eur-lex.europa.eu/legal-content/PL/TXT/PDF/?uri=C ELEX:32017H0809(20)\&from=EN [dostęp 27 marca 2019 r.]. Wymóg osiągnięcia MTO jest kluczowym elementem części prewencyjnej „Paktu stabilności i wzrostu”. Cele MTO są indywidualnie ustalane dla poszczególnych krajów, po uwzględnieniu ich sytuacji ekonomicznej i budżetowej oraz potencjalnych zagrożeń dla stabilności finansów publicznych - aktualnie minimalna wartość MTO dla niektórych państw, w tym Polski, to deficyt strukturalny (saldo skorygowane o czynniki cykliczne oraz działania jednorazowe i tymczasowe) na poziomie $1 \%$ PKB.

15 Ostrzeżenie jest już obecnie przewidziane w art. 121 ust. 4 Traktatu o funkcjonowaniu Unii Europejskiej.

16 Zwłaszcza potrzeb związanych z wymianą mebli czy wypoczynkiem rodzinnym raz w roku. Zob. publikacja GUS - Emerytury i renty w 2017 r., op. cit., s. 83.

17 Zob. „Ocenę skutków regulacji” do projektu ustawy, s. 4.

18 W roku 2017 wskaźnik ten wynosił 38,6\% i był to jeden z najgorszych wskaźników spośród badanych państw przez OECD, https://businessinsider.com.pl/twoje-pie- 
niższa. Będzie to duże wyzwanie dla przyszłych rządów, chcących uniknąć niekorzystnych zjawisk społecznych związanych m.in. z ucieczką młodych pracowników za granicę, z uwagi na podwyżki podatków i niemożność zaspokojenia potrzeb tych pracowników. Dlatego warto przypomnieć, że obecnie sytuacja emerytów i rencistów chociaż jest trudna, to nie zawsze jawi się jako najgorsza. Jak wynika z badań GUS, w roku 2017 małżeństwa z trójką lub większą liczbą dzieci nadal znajdowały się w najtrudniejszej sytuacji materialnej ${ }^{19}$. Warto też przytoczyć wyniki ostatniego sondażu $\mathrm{CBOS}^{20}$, z którego wynika, że wszystkie zapowiadane w „Nowej Piątce PiS” rozwiązania spotykają się z przychylnymi reakcjami społecznymi. Popiera je od 73\% (w przypadku zerowego PIT dla pracujących do 26. roku życia) do $84 \%$ ogółu badanych (w przypadku „trzynastej emerytury”). Jednocześnie wskazuje się, że spośród wszystkich pięciu zapowiadanych rozwiązań za najbardziej potrzebne uznawane jest rozszerzenie programu „Rodzina 500 plus", tak, aby świadczenie wychowawcze było wypłacane również na pierwsze dziecko. Jako najpotrzebniejsze wskazał je co trzeci badany (31\%).

\section{Skutki gospodarcze}

Projekt ustawy nie rodzi skutków gospodarczych, jednak można się spodziewać, niewielkiego krótkotrwałego wzrostu konsumpcji, zwłaszcza uboższych emerytów i rencistów, ze względu na ich większą skrajną skłonność do konsumpcji ${ }^{21}$.

\section{Skutki polityczne}

Projekt może rodzić pozytywne skutki polityczne, bowiem emeryci pozytywnie odbierają troskę o ich byt ekonomiczny. W dłuższym okresie polityka tzw. trzynastek dla seniorów może być dużym wyzwaniem dla kolejnych rządów z uwagi na potrzebę godzenia sprzecznych interesów osób młodych i starszych i dążenie do zapewnienia odpowiedniego poziomu wzrostu gospodarczego.

\section{Podsumowanie - ogólna ocena projektu}

- Projekt ustawy jest realizacją zapowiedzianej na konwencji partii Prawo i Sprawiedliwość tzw. trzynastej emerytury dla każdego seniora.

- Zapowiedź ta jest konkretyzowana w formie jednorazowej wypłaty świadczenia pieniężnego w 2019 r. w kwocie 1100 zł brutto dla ok. 9,8 mln osób, które to

niadze/emerytury/jaka-emeryture-dostaniesz-stopa-zastapienia-w-polsce/wse7pqv [dostęp 27 marca 2019 r.].

19 Zob. publikacja GUS - Budżety gospodarstw domowych w 2017 r., Warszawa 2018.

20 Co Polacy myślą o „Nowej Piątce PiS”?, https://fakty.interia.pl/polska/news-co-polacy-mysla-o-nowej-piatce-pis-sondaz-cbos,nId,2907853 [dostęp 27 marca 2019 r.].

21 Zob. publikacja GUS, Budżety gospodarstw domowych w 2017 r., op. cit. 
świadczenie obok pomocy dla emerytów i rencistów ma w szczególności zmniejszać różnice dochodowe w społeczeństwie.

- Proponowane w projekcie ustawy środki ułatwiają realizację celu społecznego ustawy.

- Ustawa rodzi skutki finansowe „netto” dla sektora finansów publicznych szacowane na ok. 9 mld zl, co powodować będzie przesunięcia w budżecie i w planach finansowych państwowych funduszy celowych. Może też w końcu roku - jeśli realizowane będą dalsze obietnice wyborcze - prowadzić do nowelizacji ustawy budżetowej podwyższającej poziom deficytu budżetowego.

\section{Bibliografia}

Co Polacy myślą o „Nowej Piątce PiS”?, https://fakty.interia.pl/polska/news-co-polacy-mysla-o-nowej-piatce-pis-sondaz-cbos,nId,2907853.

GUS, Budzety gospodarstw domowych w 2017 r., Warszawa 2018.

GUS, Emerytury i renty w 2017 r., Warszawa 2018. 